\title{
Hydroxychloroquine versus hydroxychloroquine-azithromycin combination therapy on QT interval prolongation of COVID-19 patients: a systematic review and meta-analysis
}

\author{
Yohanes Krisnantyo Adi Pinandito a, Qorina Nadya Salfia, Kezia Warokka Putria,

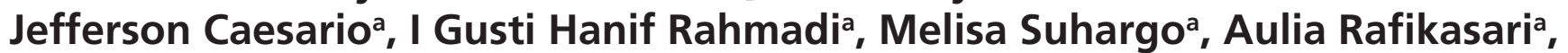 \\ Rerdin Julariob, Subur Prajitnoc
}

a Medical Co-Assistant Faculty of Medicine, Airlangga University, Surabaya, Indonesia

${ }^{b}$ Cardiology Department, Dr. Soetomo General Hospital, Surabaya, Indonesia

c Public Health and Preventive Medicine Department Faculty of Medicine, Airlangga University, Surabaya, Indonesia

\section{ARTICLE INFO}

Article history:

Submitted: 13. 1. 2021

Revised: 7. 2. 2021

Accepted: 9. 2. 2021

Available online: 12. 8. 2021

Klíčová slova:

Azitromycin

COVID-19

Hydroxychlorochin

Prodloužení intervalu QT

\section{SOUHRN}

Výzkum zaměřený na léčbu onemocnění COVID-19 vedl k použití hydroxychlorochinu (HCQ) jako jedné z možností léčby. Účinnost HCQ Ize zvýšit jeho podáváním v kombinaci s azitromycinem (AZM). Hydroxychlorochin však může spouštět arytmie v podobě prodloužení intervalu QT. Přidání AZM k HCQ by rovněž mohlo zvýšit riziko prodloužení intervalu QT. Protože mechanismus účinku těchto látek stále není přesně znám, je naprosto nezbytné provést systematický přehled výsledků dosavadního výzkumu. Cílem předložené studie bylo porovnat incidenci prodloužení intervalu QT u pacientů s onemocněním COVID-19 léčených podáváním HCQ a pacientů s kombinací HCQ-AZM. Uspořádáním se jednalo o komparativní studii dvou samostatných skupin pacientů. Údaje byly shromažd'ovány z časopisů publikovaných online v období od ledna do července 2020, v nichž se srovnávala incidence prodloužení intervalu QT u pacientů s onemocněním COVID-19 léčených bud' HCQ samotným, nebo kombinací HCQ-AZM; články byly následně zařazeny do systematického přehledu. Bylo nalezeno pět studií splňujících zadaná kritéria; výsledný vzorek zahrnoval 477 osob ve Francii a v USA. Údaje byly následně zpracovány formou deskriptivní a statistické analýzy. Statistická analýza se prováděla pomocí fixního modelu s použitím poolovaných údajủ. Analýza nenalezla žádný statisticky významný rozdíl ve výskytu prodloužení intervalu QT mezi skupinami pacientů s onemocněním COVID-19 léčenými podáváním bud' pouze HCQ, nebo kombinací HCQ-AZM (OR 1,294; 95\% Cl 0,707-2,370).

(c) 2021, ČKS.

\section{ABSTRACT}

Research related to the treatment of COVID-19 put hydroxychloroquine (HCQ)-based as a treatment option. The effectiveness of HCQ can be increased if combined with azithromycin (AZM). However, HCQ can trigger arrhythmias in the form of QT interval prolongation. Combining AZM to HCQ might also amplify the risk of QT prolongation. Since the mechanism remains elusive, a systematic review study of existing research is absolutely necessary. This study aimed to compare the incidence of QT interval prolongation in COVID-19 patients who received HCQ therapy with those who received HCQ-AZM therapy. The design used is comparative study of two independent groups. Data were collected from journals published online, from January to July 2020, regarding the comparison of QT interval prolongation between COVID-19 patients treated with HCQ only and those treated with HCQ-AZM combination, which had undergone a systematic review. Five studies that met the criteria were obtained, which included a total sample of 477 people in France and the United States. The data were then analysed descriptively and statistically. Statistical analysis was done using the fixed-effects model from the pooling of the research. It was found that there is no significant difference statistically in the QT interval prolongation between HCQ therapy group and HCQ-AZM therapy group (OR 1.294; 95\% Cl 0.707-2.370).
Keywords:

Azithromycin

COVID-19

Hydroxychloroquine

QT interval prolongation leading death causes are respiratory failure, cardiac failure and sepsis. ${ }^{1}$ Several research to find the definite therapy has been done because of the high mortality rate, though the effective definite therapy for COVID-19 has not yet been found. ${ }^{2}$ Several potential therapies are currently under investigation, including the usage of hydroxychloroquine. 
Hydroxychloroquine is an antimalarial and immunomodulatory agent, also a safer analogue of chloroquine. $^{3}$ It has demonstrated antiviral activity against SARS-CoV-2 although the mechanism of action has yet to be known. It is believed to disturb the life cycle of the virus in the cell and disturb the glycolysis process of ACE-2 receptor thus disrupting the docking process of the virus. ${ }^{4,5}$ The drug increases intracellular $\mathrm{pH}$ resulting in decreased phago-lysosome fusion, impairing viral receptor glycosylation. In addition, it has an immune-modulating effect by inhibiting toll-like receptor signalling, decreasing production of cytokines especially IL-1 and IL-6. ${ }^{3}$ Although several researches have been conducted to investigate the usage of hydroxychloroquine in decreasing the mortality rate, there are still arguments in its result. ${ }^{6}$

A study conducted in Turkey showed that combining hydroxychloroquine with azithromycin could increase its effectiveness and decrease patients' length of stay in hospital. ${ }^{6}$ Azithromycin, a macrolide antibiotic, has in vitro antiviral properties such as decreasing viral replication, blocking entrance into host cells, and a potential immunomodulating effect. ${ }^{7}$ An in vitro study demonstrated synergistic activity of the combination of hydroxychloroquine and azithromycin against SARS-CoV-2.

Although hydroxychloroquine can be a treatment for COVID-19 patients, it has shown to cause several dangerous side effects including cardiac toxicity which cause arrhythmia, QT interval prolongation, torsade de pointes, and can be fatal. Combining hydroxychloroquine and azithromycin can also increase its cardiac toxicity. ${ }^{9,10}$

This review and meta-analysis aimed to investigate the prolongation of QT interval in COVID-19 patients who received hydroxychloroquine therapy compared with COVID-19 patients who received hydroxychloroquineazithromycin combination therapy across recent studies.

\section{Methods}

The obtained data were processed with PRISMA (Preferred Reporting Items for Systematic Review and Meta Analysis) method. The search was done between July 18th to 24th 2020 on two online databases: PubMed and Google Scholar. On PubMed, using the PICO system, the keywords were: "COVID-19" (Patient/Problem), "Hydroxychloroquine" (Intervention), "Hydroxychloroquine and Azithromycin" (Comparison), and "QT interval" (Outcome). While on Google Scholar the search term used was "COVID-19 AND Hydroxychloroquine AND combination Hydroxychloroquine and Azithromycin AND prolong QT interval". The search was limited to original free full text articles and articles published from January to July 2020.

The search results were screened based on the title and abstract by seven independent reviewers. Afterwards the selected articles were checked for the full text availability and duplications amongst the selected articles. The inclusion criteria of the studies were RCT, prospective cohort, or retrospective cohort studies performed among adult patients with COVID-19 which compared patients who received hydroxychloroquine and patients who received hydroxychloroquine-azithromycin combination therapy. The outcome investigated in this study was QT interval prolongation. The quality of the study was assessed using the Effective Public Health Practice Project quality assessment tool (EPHPP) and were graded as strong, moderate, and weak. The eligibility and quality of the studies were assessed by four reviewers and the final check was done by another two reviewers.

Extraction of data was conducted independently by two authors using a standardized data collection form from Cochrane library. Extracted data included study characteristics (author, year of publication, region, time of study, study design, sample size, inclusion criteria), population character-

Table 1 - Sample size and limitation of the studies used

\begin{tabular}{|c|c|c|c|}
\hline \multirow{2}{*}{ Author } & \multicolumn{2}{|l|}{ QT interval prolongation } & \multirow{2}{*}{ Limitation } \\
\hline & HCQ theraoy & HCQ+AZT therapy & \\
\hline $\begin{array}{l}\text { Bessière et al., } \\
2020\end{array}$ & 7 of 22 patients $(31.8 \%)$ & 7 of 18 patients (38.9\%) & $\begin{array}{l}\text { - There are no baseline clinical factor data } \\
\text { related to QT prolongation }\end{array}$ \\
\hline $\begin{array}{l}\text { Saleh et al., } \\
2020\end{array}$ & $\begin{array}{l}7 \text { of } 82 \text { patients }(8.6 \%) \text { with QTc } \\
>500 \text { ms and } 5 \text { patients }(6.3 \%) \\
\text { QQTc } 60 \text { ms }\end{array}$ & $\begin{array}{l}11 \text { of } 119 \text { patients }(9.2 \%) \text { with } \\
\text { QTC }>500 \mathrm{~ms} \text { and } 21 \text { patients } \\
(17.9 \%) \Delta Q T c 60 \mathrm{~ms}\end{array}$ & $\begin{array}{l}\text { - Chloroquine is included in the sample using } \\
\text { HCQ } \\
\text { - There are no patient data that show pa- } \\
\text { tients with QTC }>500 \mathrm{~ms} \text { and } \Delta \mathrm{QTC} \geq 60 \mathrm{~ms} \\
\text { simultaneously }\end{array}$ \\
\hline $\begin{array}{l}\text { Ramireddy et al., } \\
2020\end{array}$ & $\begin{array}{l}0 \text { of } 10 \text { patients }(0 \%) \text { with QTc } \\
>500 \mathrm{~ms} \text { or } \Delta \mathrm{QTC} 60 \mathrm{~ms}\end{array}$ & $\begin{array}{l}7 \text { of } 61 \text { patients }(11.5 \%) \text { with QTc } \\
>500 \mathrm{~ms} \text { or } \Delta \text { QTc } 60 \mathrm{~ms}\end{array}$ & $\begin{array}{l}\text { - There is no control group } \\
\text { - Inconsistency of ECG checking during therapy } \\
\text { - Low sample size }\end{array}$ \\
\hline $\begin{array}{l}\text { Mercuro et al., } \\
2020\end{array}$ & $\begin{array}{l}8 \text { of } 37 \text { patients }(21.6 \%) \\
\text { - } 7 \text { patients }(18.9 \%) \text { QTc }>500 \mathrm{~ms} \\
\text { - } 3 \text { patients }(8.1 \%) \Delta \text { QTc } 60 \mathrm{~ms} \\
\text { - } 2 \text { patients }(5.4 \%) \text { have both }\end{array}$ & $\begin{array}{l}13 \text { of } 53 \text { patients }(24.5 \%) \\
\text { - } 11 \text { patients }(20.8 \%) \text { QTc } \\
>500 \mathrm{~ms} \\
\text { - } 7 \text { patients }(13.2 \%) \Delta \text { QTc } 60 \mathrm{~ms} \\
\text { - } 5 \text { patients }(9.4 \%) \text { have both }\end{array}$ & $\begin{array}{l}\text { - Not all patients experienced repeated ECG } \\
\text { to be followed up } \\
\text { - Cannot rule out cardiomyopathy and myo- } \\
\text { carditis due to COVID-19 }\end{array}$ \\
\hline $\begin{array}{l}\text { Enzman et al., } \\
2020\end{array}$ & 0 of 9 patients $(0 \%)$ & $\begin{array}{l}15 \text { of } 66 \text { patients }(22.7 \%) \\
\text { QTC }>500 \mathrm{~ms}\end{array}$ & $\begin{array}{l}\text { - Limited samples } \\
\text { - } 10 \text { patients of } 66 \text { HCT + AZM patients have } \\
\text { concomitant cardiovascular disease }\end{array}$ \\
\hline TOTAL & 22 of 160 patients $(13.8 \%)$ & 53 of 317 patients $(16.7 \%)$ & \\
\hline
\end{tabular}




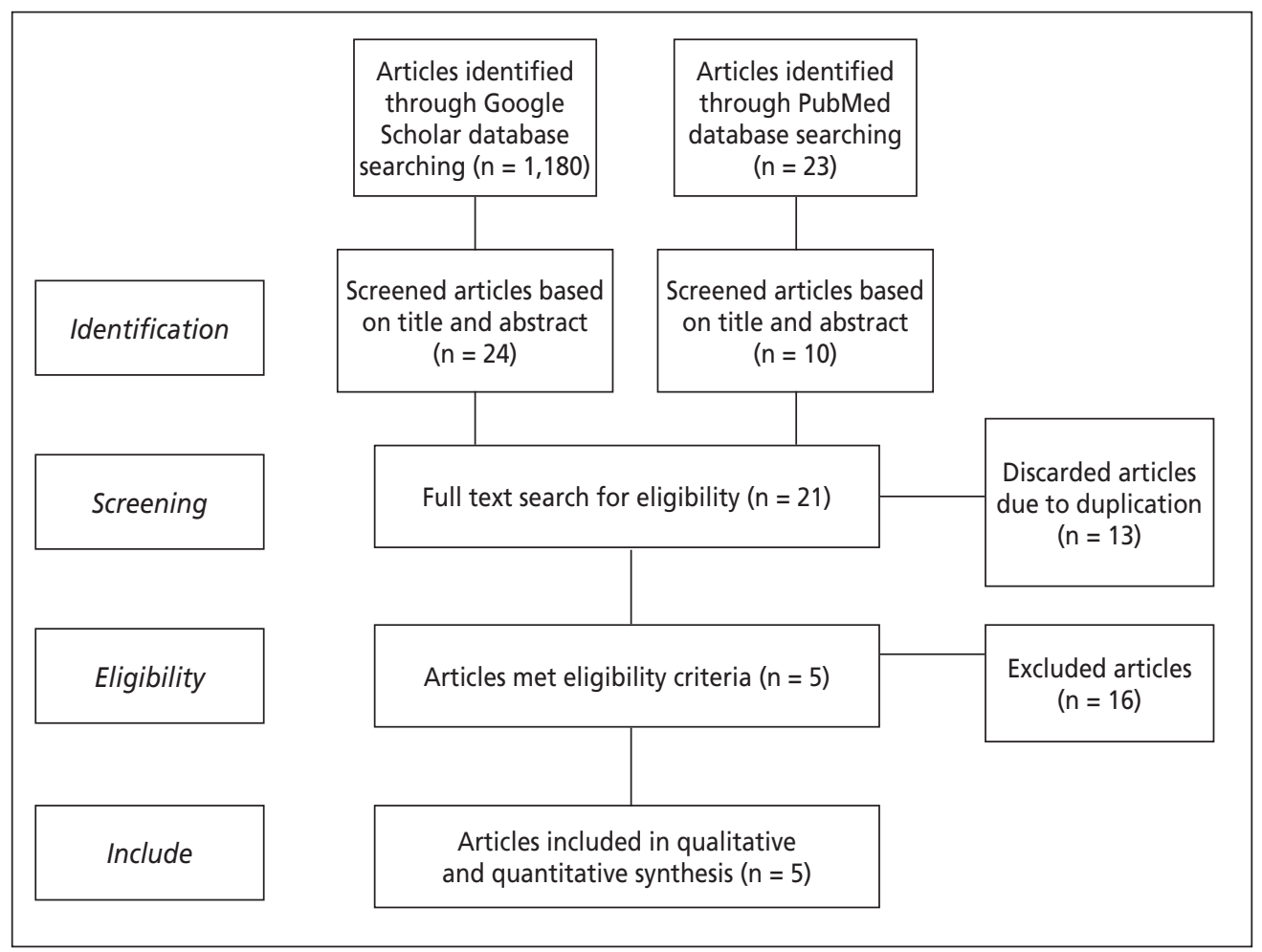

Fig. 1 - Flowchart for study design using PRISMA

istics, intervention characteristics (size of each intervention group, dosage, duration therapy, QT interval assessment) and outcomes (QT interval prolongation, limitation of study).

Statistical analysis was performed using CMA V3 (Comprehensive Meta Analysis V3) software. Odds Ratio (OR) was used for estimating the outcome with $95 \%$ confidence Interval ( $\mathrm{Cl})$. The fixed effects model was used with $12 \leq 50 \%$ which represents unimportant heterogeneity.

\section{Results}

\section{Qualitative synthesis}

The initial searches identified 1,203 articles and 1,182 were excluded after the title and abstracts screening process. The 21 potential studies were assessed for its full text eligibility and 16 were excluded. The excluded ones were articles other than the original article (review, trial protocol, etc.), articles which were not relevant to the study objective, and studies assessing the QT interval prolongation side effect of other COVID-19 potential therapy (Fig. 1). In the final result, 5 articles were included with 477 patients who met the inclusion criteria and could be further statistically analyzed (Table 1). ${ }^{11-15}$

Based on the EPHPP quality assessment tool, it was unclear regarding the blinding of participants. ${ }^{11-15}$ There were also absent details regarding the combined therapy and the outcome assessors in one of the studies. ${ }^{14}$ The EPHPP quality assessment tool showed 2 studies were strong in quality 8,9 and 3 studies were moderate in quality (Table 2) ${ }^{13-15}$.

Four of the studies were cohort study $11,12,14,15$ and one was repeated measure study..$^{13}$ Studies were heterogeneous in its design and sample size. Most of the studies had a larger size of sample group which received combined hydroxychloroquine and azithromycin. There was some difference in dosage and duration of the therapy used among the studies. One of the studies did not mention the dosage and duration of the hydroxychloroquine and azithromycin combination therapy. ${ }^{14}$ The assessment of QTc interval was carried out once every day before, during, and after the interventional therapy. Only one study did not mention the detailed QTc interval assessment. ${ }^{14}$ Characteristics of the selected studies can be seen in Table 3.

Table 2 - Quality assessment of the studies based on EPHPP quality assessment tool

\begin{tabular}{|l|l|l|l|l|l|l|l}
\hline Author & $\begin{array}{l}\text { A (Selection } \\
\text { bias) }\end{array}$ & $\begin{array}{l}\text { B (Study } \\
\text { design) }\end{array}$ & $\begin{array}{l}\text { C (Confoun- } \\
\text { ders) }\end{array}$ & D (Blinding) & $\begin{array}{l}\text { E (Data collec- } \\
\text { tion method) }\end{array}$ & $\begin{array}{l}\text { F (Withdrawal } \\
\text { and dropout) }\end{array}$ & $\begin{array}{l}\text { Global } \\
\text { rating }\end{array}$ \\
\hline Bessière et al., 2020 & Moderate & Moderate & Strong & Moderate & Moderate & Strong & Strong \\
\hline Saleh et al., 2020 & Strong & Moderate & Strong & Moderate & Strong & Moderate & Strong \\
\hline Ramireddy et al., 2020 & Moderate & Moderate & Weak & Moderate & Strong & Strong & Moderate \\
\hline Mercuro et al., 2020 & Moderate & Moderate & Weak & Moderate & Moderate & Strong & Moderate \\
\hline Enzmann et al., 2020 & Moderate & Moderate & Weak & Moderate & Strong & Strong & Moderate \\
\hline
\end{tabular}




\begin{tabular}{|c|c|c|c|c|c|}
\hline 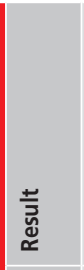 & 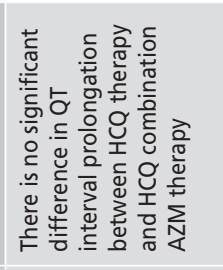 & 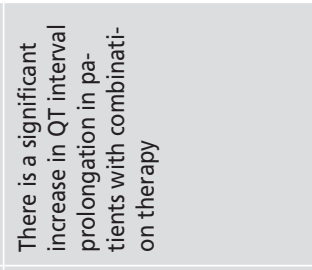 & 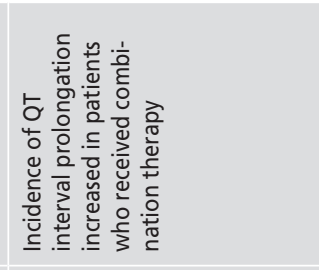 & 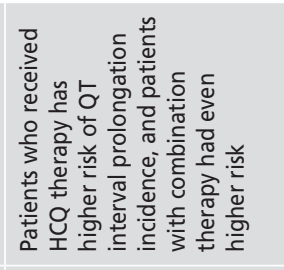 & 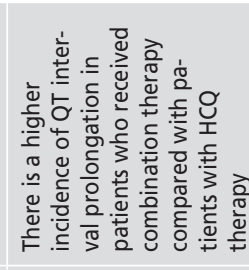 \\
\hline 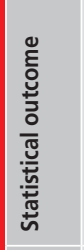 & 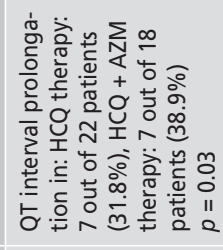 & 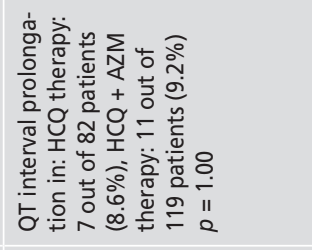 & 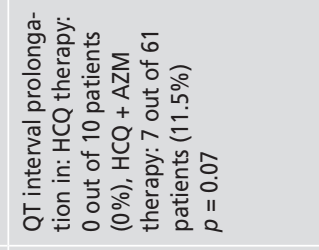 & 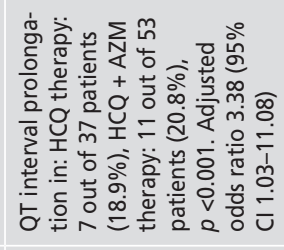 & 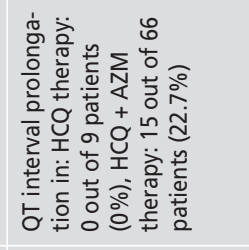 \\
\hline 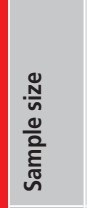 & 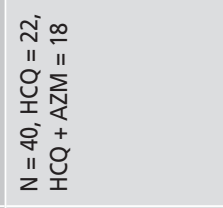 & 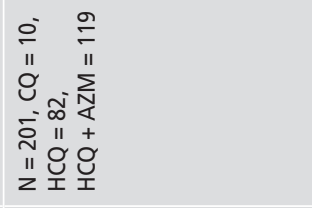 & 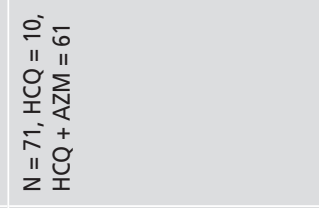 & 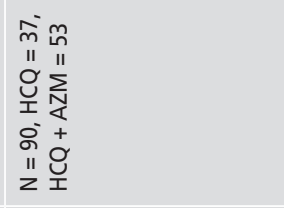 & 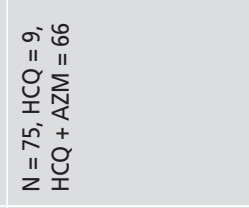 \\
\hline 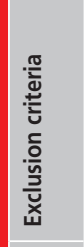 & 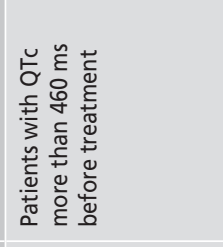 & 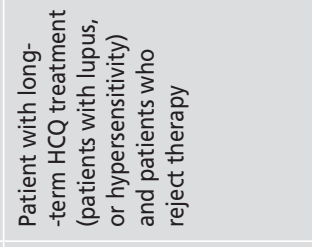 & 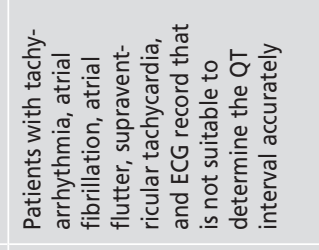 & 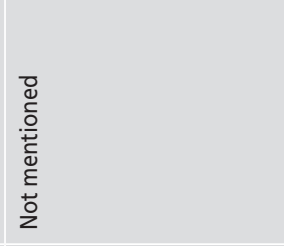 & 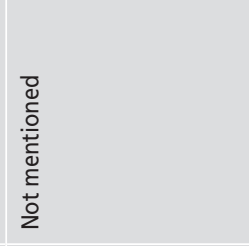 \\
\hline 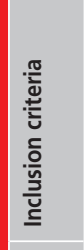 & 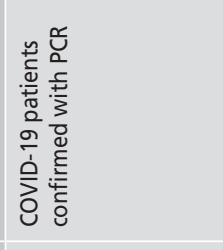 & 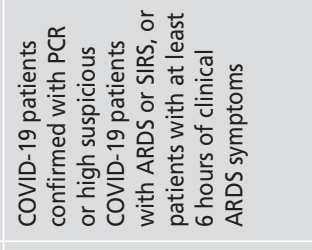 & 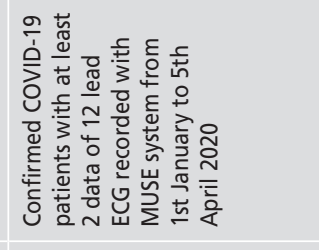 & 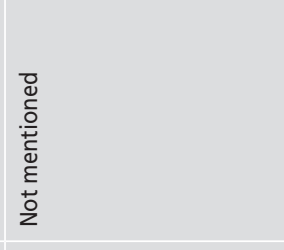 & 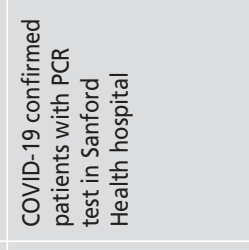 \\
\hline 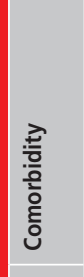 & 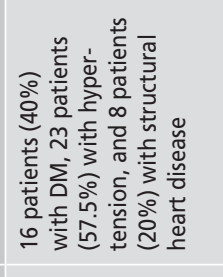 & 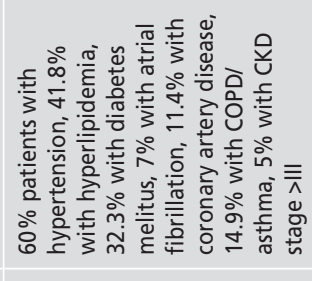 & 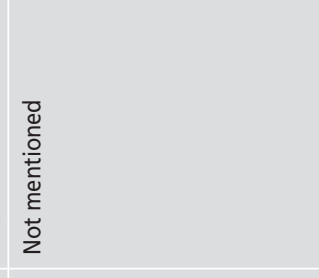 & 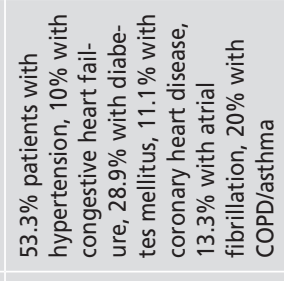 & 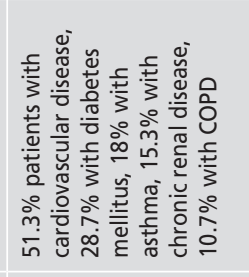 \\
\hline 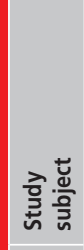 & 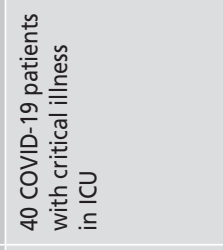 & 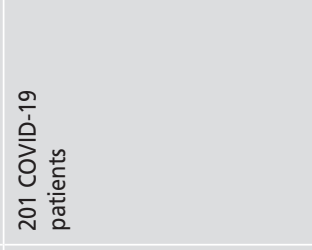 & 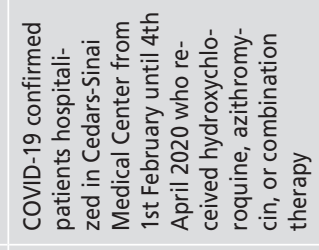 & 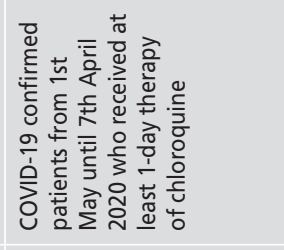 & 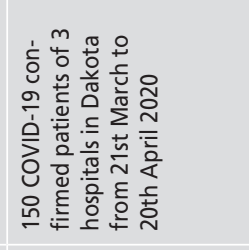 \\
\hline 总䇋离 & 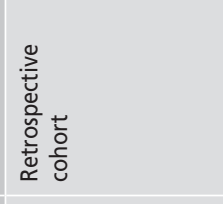 & 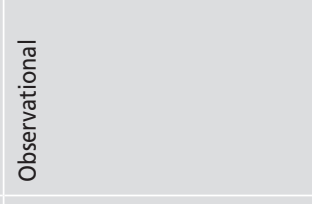 & 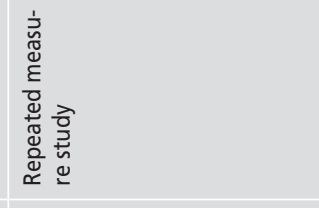 & 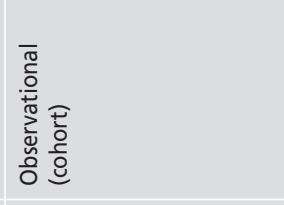 & $\begin{array}{l}\text { to } \\
\text { 훙 }\end{array}$ \\
\hline 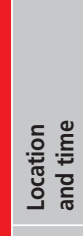 & 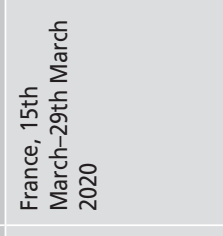 & 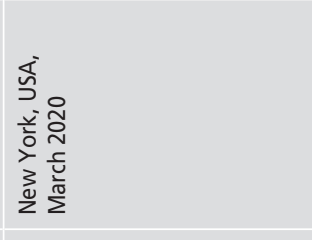 & 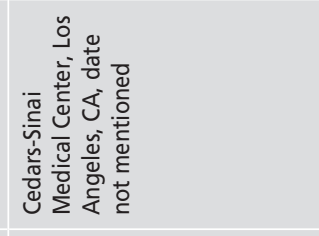 & 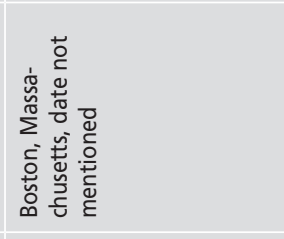 & 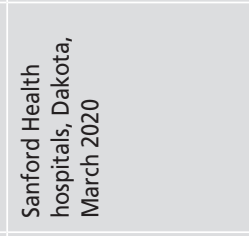 \\
\hline 嵩 & 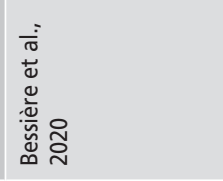 & 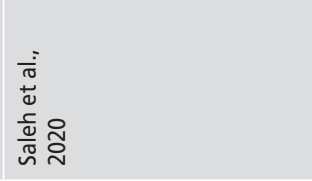 & 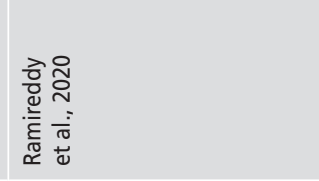 & 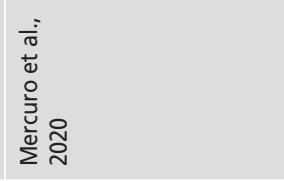 & 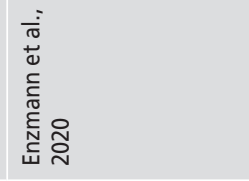 \\
\hline
\end{tabular}


Fig. 2 - Forest plot of pooled odds ratios (ORs)

\begin{tabular}{|c|c|c|c|c|c|c|c|c|c|c|c|}
\hline \multirow[t]{2}{*}{ Model } & \multirow[t]{2}{*}{ Study name } & \multicolumn{5}{|c|}{ Statistics for each study } & \multicolumn{5}{|c|}{ Odds ratio and $95 \% \mathrm{Cl}$} \\
\hline & & Odds ratio & Lower limit & Upper limit & Z-value & $p$-value & 0.01 & 0.10 & 1.00 & 10.00 & 100.00 \\
\hline & Bessière et al., 2020 & 1.364 & 0.370 & 5.028 & 0.466 & 0.641 & & & & & \\
\hline & Saleh et al., 2020 & 1.091 & 0.405 & 2.944 & 0.173 & 0.863 & & & & & \\
\hline & Ramireddy et al., 2020 & 2.890 & 0.153 & 54.552 & 0.708 & 0.479 & & & & & \\
\hline & Mercuro et al., 2020 & 1.122 & 0.390 & 3.231 & 0.214 & 0.830 & & & & & \\
\hline & Enzman et al., 2020 & 5.718 & 0.315 & 103.923 & 1.178 & 0.239 & & & & & \\
\hline Fixed & & 1.284 & 0.707 & 2.370 & 0.835 & 0.404 & & & + & & \\
\hline
\end{tabular}

\section{Quantitative synthesis}

We performed a meta-analysis on 5 studies (477 patients) regarding the QT interval prolongation between $\mathrm{CO}$ VID-19 patients who received hydroxychloroquine and COVID-19 patients who received combined hydroxychloroquine-azithromycin therapy. The meta-analysis showed that there is no statistically significant difference in QT interval prolongation between group of patients which received hydroxychloroquine and group of patients which received combined hydroxychloroquine-azithromycin therapy (OR 1.294; 95\% Cl 0.707-2.370; p-value 0.404) (Table 4, Fig. 2).

\section{Discussion}

By the end of 2020, hydroxychloroquine and chloroquine used for COVID-19 treatment, have been prohibited by The United States Food and Drug Administration (FDA) and World Health Organization (WHO) because of its ineffectiveness and inability to reduce mortality. ${ }^{16,17}$ Despite that fact, several studies stated that there are benefits of using hydroxychloroquine and chloroquine in COVID-19 treatment. ${ }^{18}$ The American Thoracic Society recommends the use of hydroxychloroquine and chloroquine in hospitalized patients with evidence of pneumonia on a case-by-case basis. ${ }^{19}$ Meanwhile, the Indian Medical Research Council is one of the first medical councils worldwide to issue recommendations for hydroxychloroquine prophylaxis among healthcare providers and close contacts involved in COVID-19 treatment or suspected patients, asymptomatic healthcare workers stationed in non-COVID-19 areas and hospitals, asymptomatic front-line personnel such as those involved in surveillance, police, and paramilitary services. ${ }^{20}$ This shows that there are still potential benefits in using hydroxychloroquine for COVID-19 treatment. For groups which still use hydroxychloroquine as treatment modalities for COVID-19, its adverse effect shall not be left out, including prolonged QTC.

In this study, three studies stated that there is a relationship between hydroxychloroquine treatment with prolonged QTc although not statistically significant. ${ }^{11,12,14}$ One study only showed clinical results without statistical analysis. ${ }^{12}$ Other studies found no relationship between hydroxychloroquine treatment and prolonged QTC. ${ }^{13,15}$ Different results in the studies could be caused by several factors such as small number of study samples, patient's clinical condition, and also existing cardiac disease like cardiomyopathy and myopathy that was hard to be excluded. ${ }^{14}$ The use of vasoactive drugs and Simplified Acute Physiology Score (SAPS) II can also significantly influence the presence of a prolonged QT. ${ }^{11}$ Absence of prolonged QTc interval in several studies could cause bias in determining the adverse event which might result in double counted or uncounted data. ${ }^{12}$ Additional drugs used in the treatment like loop diuretic could also prolong QTC interval. Incomplete data regarding patient's symptoms before admitted to the hospital could also create bias in the reviewed studies. ${ }^{13}$

Two of the reviewed studies showed no prolonged QTC interval with hydroxychloroquine therapy. This could be caused by the small number of samples which received hydroxychloroquine therapy in both studies compared to the samples which received hydroxychloroquine-azithromycin combination therapy. Because of that, it couldn't be proved that there were no correlations between hydroxychloroquine therapy and prolonged QTc interval. ${ }^{13}$

In the five studies reviewed by the author, there were almost uniform results in which populations with hydroxychloroquine-azithromycin combination therapy had a QTc interval prolongation >500 ms. As one of COVID-19 choices of antiviral treatment, the combination regimen of hydroxychloroquine and azithromycin has been con-

\begin{tabular}{|c|c|c|c|c|c|c|c|}
\hline \multirow{2}{*}{ Author } & \multicolumn{2}{|c|}{$\begin{array}{l}\text { Combination hydroxychloroquine- } \\
\text {-azithromycin therapy }\end{array}$} & \multicolumn{2}{|c|}{ Hydroxychloroquine therapy } & \multirow{2}{*}{$\begin{array}{l}\text { Odds } \\
\text { ratio }\end{array}$} & \multirow{2}{*}{$\begin{array}{l}\text { Lod } \\
\text { odds } \\
\text { ratio }\end{array}$} & \multirow{2}{*}{ Std. err } \\
\hline & $\begin{array}{l}\text { Interval } \\
\text { QTc }>500 \text { ms }\end{array}$ & $\begin{array}{l}\text { Interval } \\
\text { QTc } \leq 500 \mathrm{~ms}\end{array}$ & $\begin{array}{l}\text { Interval } \\
\text { QTc }>500 \text { ms }\end{array}$ & $\begin{array}{l}\text { Interval } \\
\text { QTc } \leq 500 \mathrm{~ms}\end{array}$ & & & \\
\hline Bessière et al., 2020 & $7(38 \%)$ & $11(61 \%)$ & $7(31.8 \%)$ & $15(68.2 \%)$ & 1.364 & 0.310 & 0.666 \\
\hline Saleh et al., 2020 & $11(9.2 \%)$ & $108(90.7 \%)$ & $7(8.5 \%)$ & $75(91.5 \%)$ & 1.091 & 0.087 & 0.506 \\
\hline Ramireddy et al., 2020 & $7(11.5 \%)$ & $54(88.5 \%)$ & $0(0 \%)$ & $10(100 \%)$ & 2.890 & 1.061 & 1.499 \\
\hline Mercuro et al., 2020 & $11(20.8 \%)$ & $42(79.2 \%)$ & $7(18.9 \%)$ & $30(81.1 \%)$ & 1.122 & 0.116 & 0.539 \\
\hline Enzmann et al., 2020 & $15(22.7 \%)$ & $51(77.3 \%)$ & $0(0 \%)$ & $9(100 \%)$ & 5.718 & 1.744 & 1.480 \\
\hline Total & $51(16.1 \%)$ & $266(83.9 \%)$ & $21(13.1 \%)$ & $139(86.9 \%)$ & & & \\
\hline
\end{tabular}


siderably investigated regarding its effectiveness and safety. ${ }^{11-15,21,22}$ Unfortunately, there is still a debatable discussion following that topic since there is not yet any research regarding this treatment with randomized blinded controlled clinical trials design. ${ }^{23}$

Theoretically, combining azithromycin with hydroxychloroquine might worsen QT prolongation incidence, compared to single therapy of hydroxychloroquine. However, this study proves that there is no significant difference among both regimens. This may be caused by the study that provides as data a different number of samples, in which there is an unproportioned number between each group, as well as inconsistent total sample between each study. ${ }^{13}$ Jankeson et al. ${ }^{24}$ suggested that it was hydroxychloroquine which has an important role in causing prolonged QTC interval. Nevertheless, the fact that limited study regarding the difference between hydroxychloroquine and combination of hydroxychloroquine-azithromycin to their effect of QT prolongation should also be anticipated.

This study has several limitations. The fact that there is no data in the reviewed studies about the duration of patient's symptoms before admission to the hospital can cause bias regarding the history and duration of COVID-19 infection. Another thing is that several reviewed studies only gave clinical results without statistically analysing them because of the small number of the study sample and the non-randomized study sample. The reviewed studies had different dosage and duration of the therapy given between each study. There is one study that didn't mention the dosage and the duration of therapy given.

\section{Conclusion}

In this study, involving 477 patients in the five publications studied, it can be concluded that there was no significant difference of the QTc prolonged interval in COVID-19 patients who received hydroxychloroquine therapy with those who received hydroxychloroquine-azithromycin combination therapy. However, there are some differences in treatment from each journal studied, namely the dose used, duration of therapy, inconsistencies in ECG measurements during therapy, and other risk factors that can also cause prolongation of the QTc interval.

\section{Conflict of interest}

There is no conflict of interest in this study.

\section{Funding body}

None

\section{References}

1. Chen N, Zhou M, Dong X, et al. Epidemiological and clinical characteristics of 99 cases of 2019 novel coronavirus pneumonia in Wuhan, China: a descriptive study. Lancet 2020;395:507-513.

2. Geleris J, Sun Y, Platt J, et al. Observational Study of Hydroxychloroquine in Hospitalized Patients with Covid-19. N Engl J Med 2020;382:2411-2418.

3. Savarino A, Boelaert JR, Cassone A, et al. Effects of chloroquine on viral infections: an old drug against todays diseases. Lancet Infect Dis 2003;3:722-727.

4. Celik I, Onay-Besikci A, Ayhan-Kilcigil G. Approach to the mechanism of action of hydroxychloroquine on SARS-CoV-2: a molecular docking study. J Biomol Structur Dyn 2020 Jul 17:17. doi: 10.1080/07391102.2020.1792993. Epub ahead of print.
5. Hashem A, Alghamdi B, Algaissi A, et al. Therapeutic use of chloroquine and hydroxychloroquine in COVID-19 and other viral infections: A narrative review. Travel Med Infect Dis 2020;35:101735.

6. Tanriverdi E, Çörtük M, Yildirim BZ, et al. The use of hydroxychloroquine plus azithromycin and early hospital admission are beneficial in Covid-19 patients: Turkey experience with real-life data. Turk J Med Sci 2021;51:10-15.

7. Tran $\mathrm{DH}$, Sugamata R, Hirose $\mathrm{T}$, et al. Azithromycin, a 15-membered macrolide antibiotic, inhibits influenza $A(H 1 N 1)$ pdm09 virus infection by interfering with virus internalization process. J Antibiot (Tokyo) 2019;72:759-768.

8. Andreani J, Bideau ML, Duflot I, et al. In vitro testing of combined hydroxychloroquine and azithromycin on SARS-CoV-2 shows synergistic effect. Microb Pathog 2020;145:104228.

9. Roden D, Harrington R, Poppas A, Russo A. Considerations for Drug Interactions on QTc Interval in Exploratory COVID-19 Treatment. J Am Coll Cardiol 2020;75:2623-2624.

10. Funck-Brentano C, Salem J, et al. Response to the editorial "COVID-19 in patients with cardiovascular diseases". Arch Cardiovasc Dis 2020;113:367-368.

11. Bessière $F$, Roccia $H$, Delinière $A$, et al. Assessment of $Q T$ Intervals in a Case Series of Patients With Coronavirus Disease 2019 (COVID-19) Infection Treated With Hydroxychloroquine Alone or in Combination With Azithromycin in an Intensive Care Unit. JAMA Cardiology 2020;5:1067.

12. Saleh M, Gabriels J, Chang D, et al. Effect of Chloroquine, Hydroxychloroquine, and Azithromycin on the Corrected QT Interval in Patients With SARS-CoV-2 Infection. Circ Arrhythm Electrophysiol 2020;13:e008662.

13. Ramireddy A, Chugh $H$, Reinier $K$, et al. Experience With Hydroxychloroquine and Azithromycin in the Coronavirus Disease 2019 Pandemic: Implications for QT Interval Monitoring. J Am Heart Assoc 2020;9:e017144.

14. Mercuro N, Yen C, Shim D, et al. Risk of QT Interval Prolongation Associated With Use of Hydroxychloroquine With or Without Concomitant Azithromycin Among Hospitalized Patients Testing Positive for Coronavirus Disease 2019 (COVID-19). JAMA Cardiology 2020;5:1036.

15. Enzmann M, Erickson M, Grindeland C, et al. Treatment and preliminary outcomes of 150 acute care patients with COVID-19 in a rural health system in the Dakotas. Epidemiol Infect 2020;148:e124.

16. FDA, 2020. FDA Cautions against Use of Hydroxychloroquine or Chloroquine for COVID-19 outside of the Hospital Setting or a Clinical Trial Due to Risk of Heart Rhythm Problems. FDA. https://www.fda.gov/drugs/drug-safety-and-availability/fdacautions-against-use-hydroxychloroquine-or-chloroquine-covid19-outsid e-hospital-setting-or.

17. WHO, 2020. "Solidarity" clinical trial for COVID-19 treatments. https://www.who.int/emergencies/diseases/novelcoronavirus-2019/global-research-on-novel-coro navirus-2019ncov/solidarity-clinical-trial-for-covid-19-treatments. Accessed 1st June 2020.

18. Singh $\mathrm{H}$, Chauhan $\mathrm{P}$, Kakkar AK. Hydroxychloroquine for the treatment and prophylaxis of COVID-19: The journey so far and the road ahead. Eur J Pharmacol 2021;890:173717.

19. Covid-19, 2020. Interim Guidance on Management Pending Empirical Evidence. From an American Thoracic Society-led International Task Force. https://www.thoracic.or g/professionals/ clinical-resources/disease-related-resources/covid-19-guidance.pdf.

20. Revised advisory on the use of Hydroxychloroquine (HCQ) as prophylaxis for SARS-CoV- 2 infection. https://www.icmr.gov.in/ $\mathrm{pdf} / \mathrm{covid} / \mathrm{techdoc}$ V5_Revised_advisory_on _the_use_of_HCQ SARS_CoV2_infection.pdf, 2020.

21. Gautret $P$, Lagier J, Parola $P$ et al. Hydroxychloroquine and azithromycin as a treatment of COVID-19: results of an openlabel non-randomized clinical trial. Int J Antimicrob Agents 2020;56:105949.

22. Cipriani A, Zorzi A, Ceccato D, et al. Arrhythmic profile and 24hour QT interval variability in COVID-19 patients treated with hydroxychloroquine and azithromycin. Int J Cardiol 2020;316:280-284.

23. Popescu C, Fischer P. Hydroxychloroquine-azithromycin for COVID-19 - Warranted or dangerous? Travel Med Infect Dis 2020;35:101764.

24. Jankelson L, Karam G, Becker M, et al. QT prolongation, torsades de pointes, and sudden death with short courses of chloroquine or hydroxychloroquine as used in COVID-19: A systematic review. Heart Rhythm 2020;17:1472-1479. 